\title{
A Study on Urban Inundation Using SWMM in Busan, Korea, Using Existing Dams and Artificial Underground Waterways
}

\author{
Yeon-Moon Choo ${ }^{1}\left(\mathbb{D}\right.$, Sang-Bo Sim ${ }^{2} \mathbb{D}$ and Yeon-Woong Choe ${ }^{2, *}$ \\ 1 Institute of Industrial Technology, Pusan National University, Busan 46241, Korea; chooyean@naver.com \\ 2 Department of Civil and Environmental Engineering, Pusan National University, Busan 46241, Korea; \\ thfkthf@naver.com \\ * Correspondence: ywchoe@pusan.ac.kr; Tel.: +82-051-510-7654
}

Citation: Choo, Y.-M.; Sim, S.-B.; Choe, Y.-W. A Study on Urban Inundation Using SWMM in Busan, Korea, Using Existing Dams and Artificial Underground Waterways. Water 2021, 13, 1708. https:// doi.org/10.3390/w13121708

Academic Editors: Enrico Creaco and Marco Franchini

Received: 29 March 2021

Accepted: 15 June 2021

Published: 20 June 2021

Publisher's Note: MDPI stays neutral with regard to jurisdictional claims in published maps and institutional affiliations.

Copyright: (C) 2021 by the authors. Licensee MDPI, Basel, Switzerland. This article is an open access article distributed under the terms and conditions of the Creative Commons Attribution (CC BY) license (https:// creativecommons.org/licenses/by/ $4.0 /)$.

\begin{abstract}
The annual average rainfall in Busan area is increasing, causing frequent flooding of Busan's Suyeong and Oncheon rivers. Due to the increase in urbanized areas and climate change, it is difficult to reduce flood damage. Therefore, new methods are needed to reduce urban inundation. This study models the effects of three flood reduction methods involving Oncheon River, Suyeong River, and the Hoedong Dam, which is situated on the Suyeong. Using EPA-SWMM, a virtual model of the dam and the rivers was created, then modified with changes to the dam's height, the installation of a floodgate on the dam, and the creation of an underground waterway to carry excess flow from the Oncheon to the Hoedong Dam. The results of this study show that increasing the height of the dam by $3 \mathrm{~m}, 4 \mathrm{~m}$, or $6 \mathrm{~m}$ led to a $27 \%, 37 \%$, and $48 \%$ reduction in flooding, respectively, on the Suyeong River. It was also found that installing a floodgate of $10 \times 4 \mathrm{~m}, 15 \times 4 \mathrm{~m}$, or $20 \times 4 \mathrm{~min}$ the dam would result in a flood reduction of $2.7 \%$ and $2.9 \%$, respectively. Furthermore, the construction of the underground waterway could lead to an expected $25 \%$ flood reduction in the Oncheon River. Measures such as these offer the potential to protect the lives and property of citizens in densely populated urban areas and develop sustainable cities and communities. Therefore, the modifications to the dam and the underground waterway proposed in this study are considered to be useful.
\end{abstract}

Keywords: SWMM; urban flood reduction; underground waterway

\section{Introduction}

Recently, heavy rains have occurred frequently due to abnormal weather conditions, and the increase in areas impervious to rainfall due to urbanization is increasing the damage caused by urban flooding [1,2]. The average annual rainfall in Korea's Busan region has increased from $1255 \mathrm{~mm}$ in the 1970 s to $1407 \mathrm{~mm}$ in the 2000s. In particular, major heavy rains in the summers of 2014 and 2020 caused deaths and extensive flood damage in Busan and nearby areas. In these years, Busan suffered rainfall of about $244 \mathrm{~mm}$ and $205 \mathrm{~mm}$, respectively. It is therefore clear that a solution is needed for the problem of flooding in urban areas.

Various studies on urban flood management have been undertaken. Hoang et al. discussed methodologies for evaluating benefit profiles and benefit intensity, and commented on benefit dependencies for urban flood management utilizing green infrastructure [3]. Vercruysse and Dawson proposed infrastructure for flood management [4]. Wu et al. proposed a model to effectively assess flood disaster risk in response to climate change [5]. Mei et al. simulated a numerical model to discuss flood risk management and urban flood prevention [6]. Cristiano et al. conducted research on reducing urban flooding in response to urbanization and climate change [7].

Several methods of flood control involving dams have been proposed. Blazkova and Beven conducted simulations to estimate the frequency of flooding for dams in the Czech Republic [8]. Badenko et al. conducted research on how to transform existing dams into a means of disaster prevention [9] in a study similar to this one, but also considered 
environmental impacts. Mei et al. conducted a flood prevention study based on historical data [10].

Many studies have performed urban flood analysis by means of computer software programs. Sharif and Hansen used the SWMM model to analyze flooding and recommended the method as a platform for flood alert system management [11]. Jang produced a study on the selection of facilities for damage prevention through SWMM, analyzing the situation before and after the installation of such facilities [12]. Meanwhile, Lee et al. simulated a heavily urbanized area in order to identify the ideal location for damage prevention facilities, and estimated the effect they would have on reducing flooding [13]. Shin et al. used SWMM's LID capabilities in their study area to conduct environmental impact and outflow analyses [14]. Jiang et al. predicted urban flooding in a simulated urban area [15]. Kim and Lee used weather data to simulate urban flooding and proposed the construction of underground storage facilities to relieve flooding in areas where it is expected [16].

Rai et al. used a rainfall-runoff simulation to conduct flood modeling in order to realistically predict the maximum flow required for flood prevention [17]. Babaei et al. focused on watersheds, using SWMM to address the insufficient urban drainage system of a large city [18]. Hasan et al. used SWMM to predict water levels and maximum discharge of a drainage system in an area where flood frequency is increasingly rapidly every year [19]. Choo et al. proposed a flood prediction method aimed at reducing flooding in urban areas, involving improved measurements of four flow levels in water pipes, at 50\% capacity, $70 \%$ capacity, $100 \%$ capacity, and the initial flooding [20].

In Busan, there are two important rivers: the Suyeong and the Oncheon. The Suyeong river basin has an area of $200.06 \mathrm{~km}^{2}$ and its lower course passes through the city of Busan. The Oncheon River flows to the mouth of the Suyeong, to an upstream point of about $3.1 \mathrm{~km}$, and its drainage basin is $56.28 \mathrm{~km}^{2}$. Regarding its topographical features, the upper reaches of the Oncheon River run through a mountainous region, while the middle and lower reaches are relatively flat; hence, the urban areas of Busan were developed there. When heavy rainfall events occur, the river frequently floods, causing considerable damage to urban areas. Therefore, measures to prevent the flooding of this major urban river in heavy rain are needed.

To develop a proposal to reduce the flooding of the Suyeong and Oncheon rivers and make the inhabited areas they run through safer to live, we created a simulation in which the height of the Hoedong Dam was increased, a floodgate were installed, and an underground waterway was constructed. The height of the Hoedong Dam was increased so that it could hold more water and reduce the flooding of the Suyeong River. The underground waterway was included to move water from the Oncheon basin to the Hoedong Dam, because there are no dams on the Oncheon River. The extra floodgate in the Hoedong Dam was added in order to control the flooding of the Suyeong River.

The Hoedong Dam, located on the middle reaches of the Suyeong River, was constructed in 1946 to supply water. It was not intended as a means of urban disaster prevention, having been built at a time when there was no major flood risk in Busan. However, because incidences of flood damage due to abnormal weather have been increasing steadily since 2014, Busan Metropolitan Government is planning to build new disaster prevention facilities, although are hampered by a lack of available land and high construction costs due to urbanization.

For example, the new pump station planned for Busan will have a drainage capacity of $600 \mathrm{~m}^{3} / \mathrm{min}$, and will cost approximately USD 4,000,000. If the Hoedong Dam's functions are extended to flood prevention and the suggested underground waterway is constructed, the expected cost would be approximately USD 360,000, which is around 9\% of the cost of the new pump station. Therefore, turning Hoedong into a multipurpose dam is economically viable because it does not require a new site and construction costs would be much lower than for a new pump station. This study shows that flooding can 
be reduced in various ways in urban areas where new disaster prevention facilities are difficult to build.

\section{Research Method}

This study proposes a flood reduction method for the Oncheon River involving the construction of an underground waterway to the Hoedong Dam to carry excess discharge. The selection of the Hoedong Dam, which is located on the Suyeong River, was based on its proximity, as it is located $1.2 \mathrm{~km}$ to the east of the Oncheon.

Nakdong River, the second largest river in Korea, flows $7.6 \mathrm{~km}$ away from the Oncheon, although in order for the Oncheon to drain into the Nakdong, it would have to pass through Geumjeong Mountain (elevation $801 \mathrm{~m}$ ) and the city center. However, because the Hoedong Dam on the Suyeong River is only $1.2 \mathrm{~km}$ away, the Suyeong has an advantage over the Nakdong as a destination for excess discharge from the Oncheon. In addition, there the terrain conditions between the Oncheon and Suyeong rivers are, in many ways, more favorable, with no mountains and no urban areas to traverse. If discharge from the Oncheon was drained into the Suyeong River, it would not have a significant impact on the latter.

Therefore, the construction of an underground waterway from Oncheon River to Hoedong Dam was proposed, and the effects of such a waterway on the Suyeong River were analyzed. In order to reduce flooding of the Suyeong River, two methods were applied: the reservoir capacity of the Hoedong Dam was expanded, and the outflow volume was adjusted by means of floodgates. The effect of increased reservoir capacity was modeled by augmenting the height of the dam by 3,4 , and $6 \mathrm{~m}$. The effect of floodgates was investigated by modeling three different floodgates, all $4 \mathrm{~m}$ in height, but of varying widths: 10,15 , and $20 \mathrm{~m}$.

The proposals were simulated using EPA-SWMM, in order to analyze their effect on flood reduction in the Suyeong and Oncheon rivers. The basin was modeled using EPASWMM, and 12 different time-distributed probable rainfall patterns were applied based on the Huff third quartile. In addition, actual rainfall records from 15 August 2014 and 23 July 2020, when significant flooding occurred in Busan, were run through the simulation.

The remainder of this paper is organized as follows:

1. Modeling of the drainage basin with EPA-SWMM;

2. Organization of rainfall input data;

3. Selection of flood hazard points;

4. Simulation of existing drainage basin;

5. Underground waterway construction;

6. Simulation of effects of the underground waterway;

7. Restoration of a catchment basin map to its original state;

8. Simulation after $3 \mathrm{~m}$ rise in Hoedong Dam;

9. Simulation after $4 \mathrm{~m}$ rise in Hoedong Dam;

10. Simulation after $6 \mathrm{~m}$ rise in Hoedong Dam;

11. Restoration of a catchment basin map to its original state;

12. Simulation after $10 \mathrm{~m}$ (width) $\times 4 \mathrm{~m}$ (height) floodgate installation in Hoedong Dam;

13. Simulation after $15 \mathrm{~m}$ (width) $\times 4 \mathrm{~m}$ (height) floodgate installation in Hoedong Dam;

14. Simulation after $20 \mathrm{~m}$ (width) $\times 4 \mathrm{~m}$ (height) floodgate installation in Hoedong Dam;

15. We discuss the reduction in the amount of flooding at flood hazard points for the results of the existing drainage area simulation and the drainage area simulation after the installation of the floodgate, as well as the results of the drainage area simulation after the Hoedong Dam augmentation.

\subsection{Composition of the EPA-SWMM Integration Model}

SWMM was developed with the support of the U.S. Environmental Protection Agency (EPA), and is a simulation model capable of short-term and long-term outflow simulations for urban drainage areas. EPA-SWMM is an EPA-provided SWMM. In addition 
to EPA-SWMM, there are several derived programs, including InfoSWMM, PC-SWMM, and XP-SWMM. In Korea, XP-SWMM and EPA-SWMM are most commonly used; however, XP-SWMM cannot be used to model large drainage basins, because it has limited capacity for drainage area composition. However, EPA-SWMM has no restrictions on the composition of the drainage basin, and the coding allows free control over pipes, weirs, and other facilities. In addition, because the source code is public, it has the advantage of being general-purpose and highly scalable in future programs.

The Suyeong and the Oncheon are typical urban rivers, and the flooding of such rivers poses immediate issues of safety and damage to citizens' property. Therefore, it is important to accurately simulate the degree of flooding caused by rainfall, and when such flooding occurs. Currently, HEC-RAS, which is used in river analysis, only simulates the river itself, whereas SWMM allows the modeling of a detailed drainage area, including features such as impermeable areas. It has the added advantage of analyzing the degree of flooding, enabling modelers to predict how much flood damage will occur. Due to these advantages, the flood damage analysis for this study was performed using EPA-SWMM.

\subsection{Selection of Flood Hazard Points}

Figure 1 indicates the sections of the Oncheon and Suyeong river drainage basins that formed the focus of this study. Point No. 9+900 on the Oncheon River (bottom-left image) is one of the flood hazard points selected for this study; it is located $100 \mathrm{~m}$ upstream from point No. $9+800$.

Figure 2 shows a partial longitudinal section of the Oncheon basin depicted in Figure 1. It shows that point No. $9+900$ falls in an area with a gently sloping riverbed. Due to this profile and the lack capacity for rapid discharge during heavy rains, waterflow stagnates at this point, causing frequent flooding. Therefore, this station was selected as the flood hazard point on the Oncheon River.

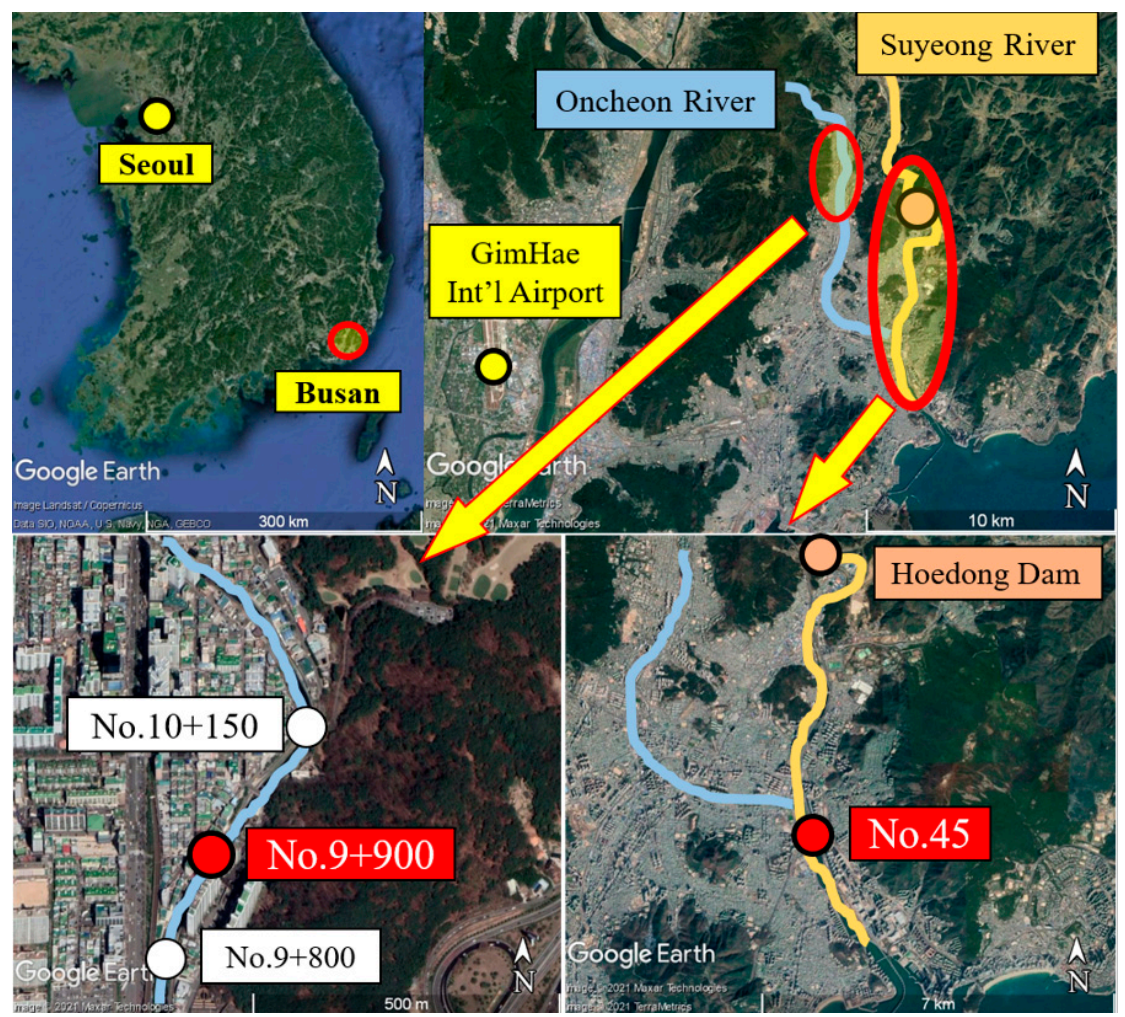

Figure 1. Study area. Point No. $10+150: 35^{\circ} 15^{\prime} 19.28^{\prime \prime}$ N, $129^{\circ} 5^{\prime} 40.11^{\prime \prime}$ E; Point No. 9+900: $35^{\circ} 15^{\prime} 12.78^{\prime \prime}$

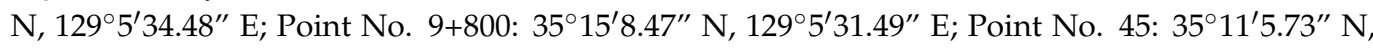
$129^{\circ} 7^{\prime} 0.96^{\prime \prime} \mathrm{E}$. 


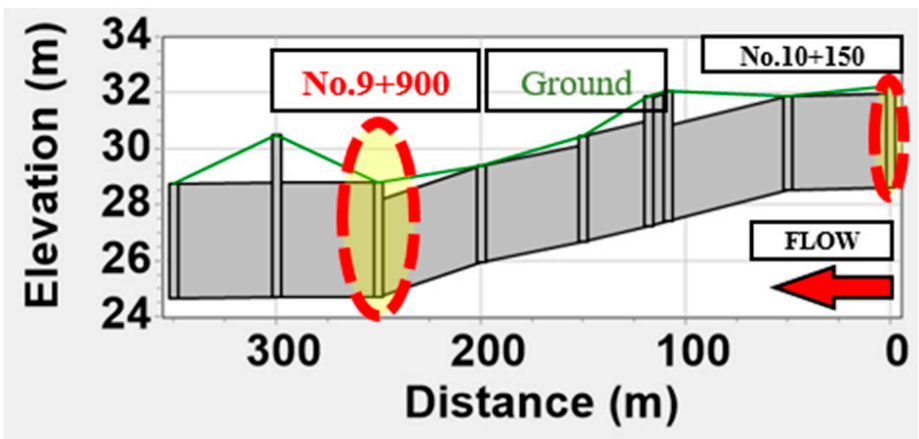

Figure 2. Longitudinal section of the Oncheon River area (partial).

In Figure 1, point No. 45 (bottom right-hand image) is a point of flood hazard on the Suyeong River. Figure 3 shows a partial longitudinal section of the Suyeong basin indicated in Figure 1. Point No. 45 also has a fairly gentle riverbed slope. Therefore, this is another point of stagnation, where water is not rapidly discharged during heavy rain, leading to frequent flooding. Another cause of flooding here is the inflow of surrounding creeks. For these reasons, No. 45 station was also selected as the flood hazard point for the Oncheon River.

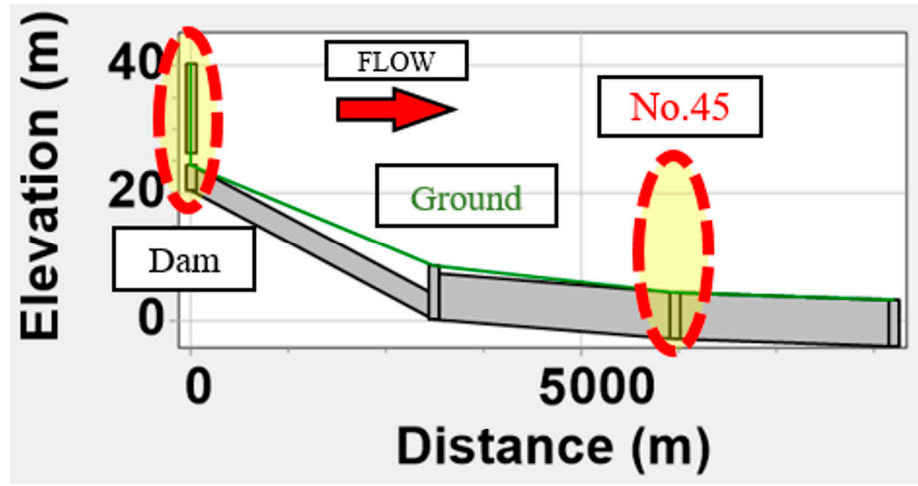

Figure 3. Longitudinal section of the Suyeong River area (partial).

\subsection{Underground Waterway Construction}

The Oncheon and Suyeong river basins were simulated, and the flooding hazard points selected. An underground waterway was simulated in order to analyze its effect on flood reduction at the Oncheon hazard point, and to analyze its impact on the Suyeong River. The underground waterway starts at point No. 10+150 and connects to Hoedong Dam (both indicated in Figure 1).

Figure 4 shows the path of the simulated underground waterway, while Figure 5 shows its longitudinal section. When the water level rises at point No. 10+150, the overflow is directed to the Hoedong Dam. The underground waterway consists of a circular concrete tunnel measuring $3.5 \mathrm{~m}$ in diameter. 


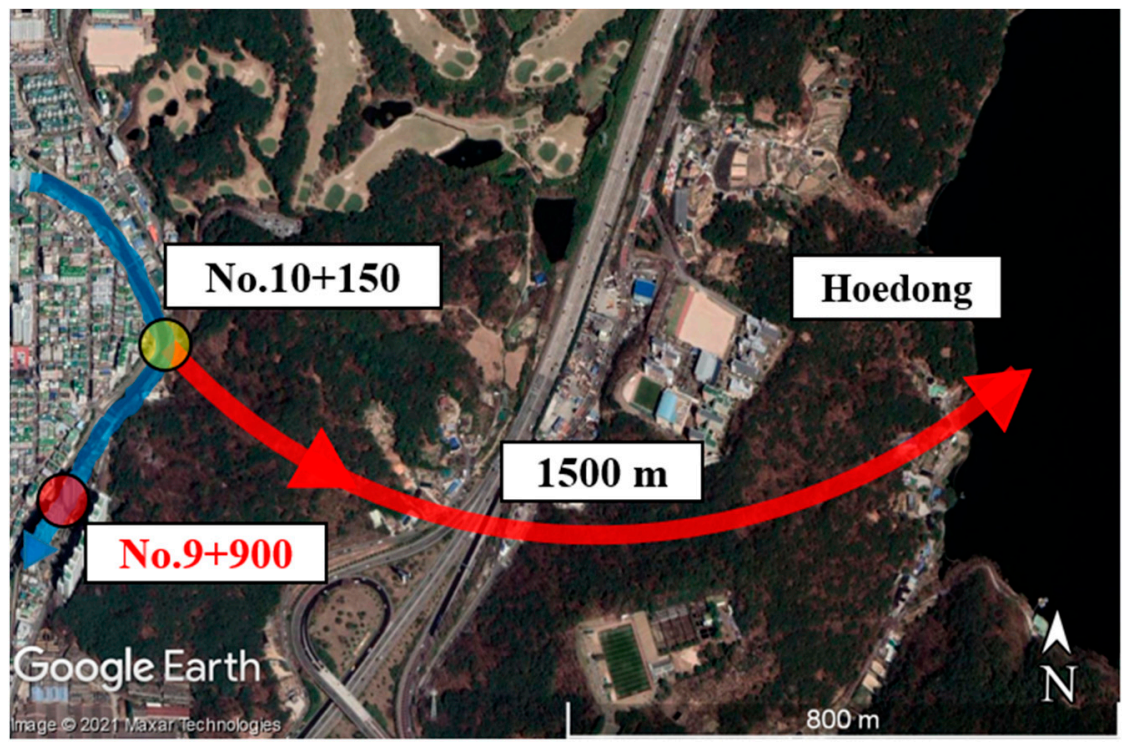

Figure 4. Route map of the underground waterway.
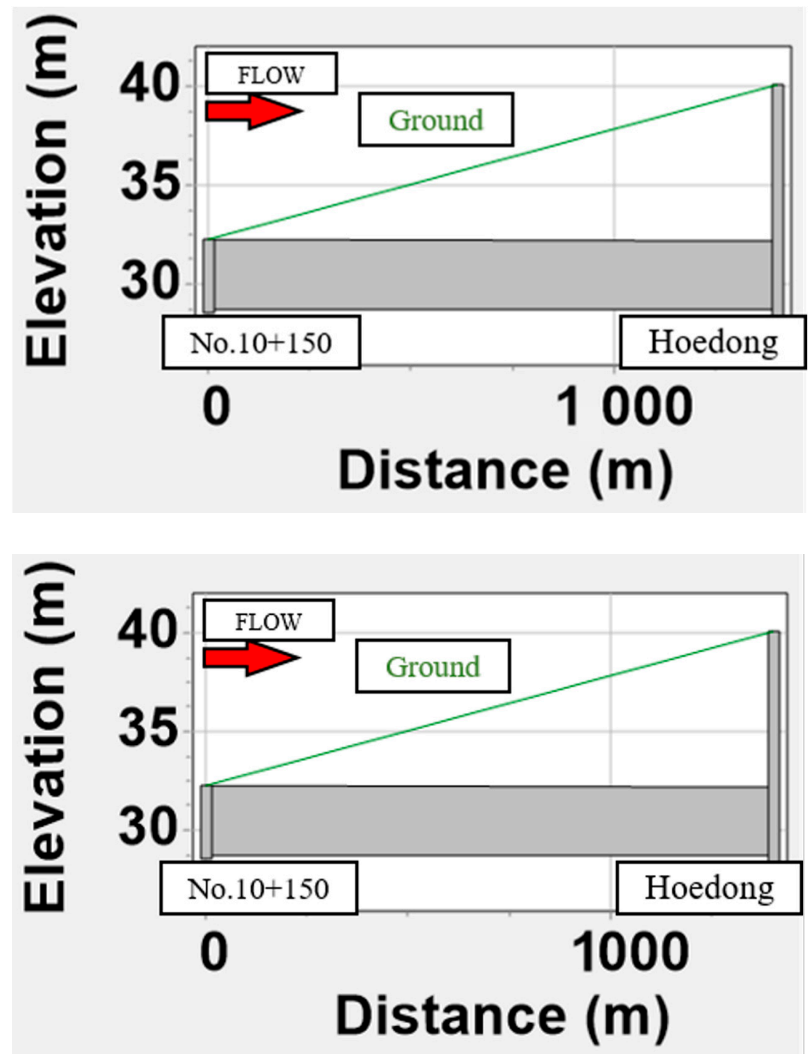

Figure 5. Longitudinal section of the underground waterway.

\subsection{Hoedong Dam Height Increase}

It was confirmed that the underground waterway did not significantly affect the Suyeong River. The height of the Hoedong Dam was increased to analyze the rate of flooding reduction at the flooding hazard point of the Suyeong River. by increments of 3, 6, and $9 \mathrm{~m}$ to analyze the reduction in flooding at the hazard point.

As the dam's height was augmented, the additional storage quantity was estimated by means of the existing content curve, as shown in Figure 6, and the drainage area drawing was utilized for estimation. These data were entered into the EPA-SWMM model, in order 
to identify the effects of each height increase on the flood hazard point on the Suyeong River.

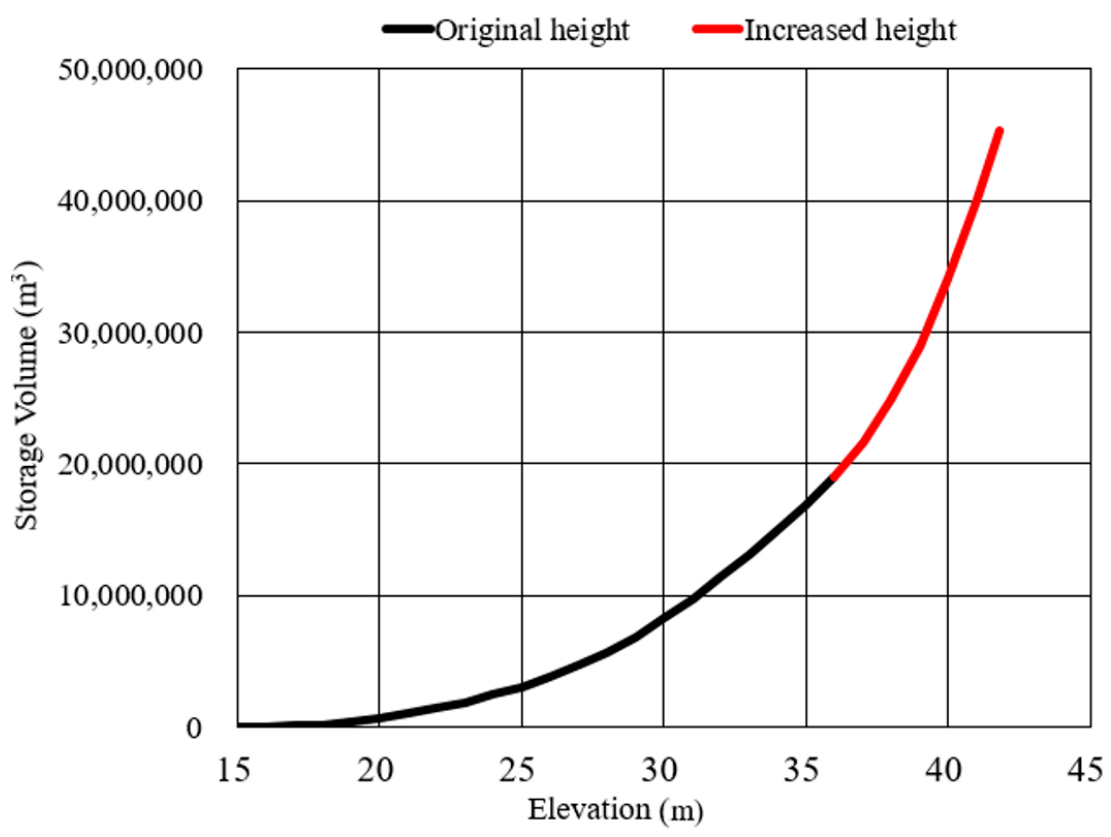

Figure 6. Storage volume according to dam elevation.

\subsection{Installing a New Floodgate on the Hoedong Dam}

The impact of floodgate installation was examined by setting the floodgate at three sizes: $10 \mathrm{~m}$ (width) $\times 4 \mathrm{~m}$ (height), $15 \mathrm{~m}$ (width) $\times 4 \mathrm{~m}$ (height), and $20 \mathrm{~m}$ (width) $\times 4 \mathrm{~m}$ (height). The floodgates for the dam were installed below the floor height of the spillway.

The opening and closing of floodgates was simulated by means of coding in EPASWMM. Since the purpose of this experiment was to reduce flood damage in the downstream areas by controlling the amount of discharge reaching them during abnormal rainfall, the following procedure was adopted. When the water level at flood hazard point No. 45 was low, the floodgate was opened, and water from the dam was discharged in advance. If the water level exceeded the designated flood level, the floodgate was closed. After the water at the flood hazard point drained to a certain level, the floodgate was opened again.

\section{Flood Reduction Effects on the Suyeong River and Oncheon River}

The storm event modeled in this study used rainfall quantiles, and simulated a total of 12 different rainfall conditions by applying durations of 60 to $180 \mathrm{~min}$ and return periods of 30, 50, 100, and 200 years. The rainfall quantile for Busan area used in this study was based on the "Improvement and Supplement of Probability Rainfall Study", published by the Ministry of Land, Infrastructure and Transport in 2011 [21]. The time distribution was applied to the third Huff quartile, which was presented as a practical safety measure by the Ministry of Land, Infrastructure and Transport study [19]. Huff's method uses a dimensionless curve. The pre-existing Huff third quartile curve for Busan is shown in Figure 7. 


\section{Huff 3}

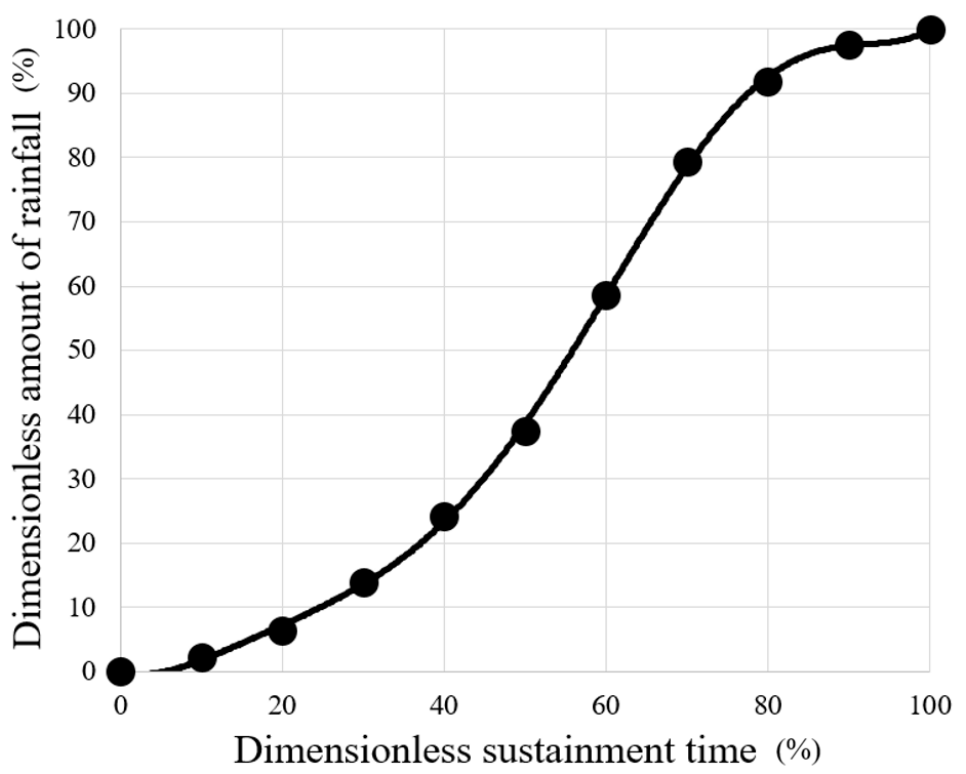

Figure 7. Huff third quartile distribution curve for Busan area.

Figures 8-11 show the degree of water reduction at the flood hazard point on the Suyeong River when the Hoedong Dam's height is augmented and a floodgate is installed; Figures 12 and 13 show graphs of the flood hazard point on the Oncheon River before and after the underground waterway is utilized. Taken together, these graphs indicate that, compared to the original model of the drainage basin, flooding started later and finished sooner when the Hoedong Dam's capacity was augmented, floodgates were installed, and the underground waterway was used.

Such a scenario makes it easier for the authorities to respond in a timely manner in the event of heavy rain. In addition, given that the overall amount of flooding is significantly reduced by these measures, we judge that this model can be applied in practice and considered to be of value, in that it can significantly increase the safety of citizens and minimize damage to property.

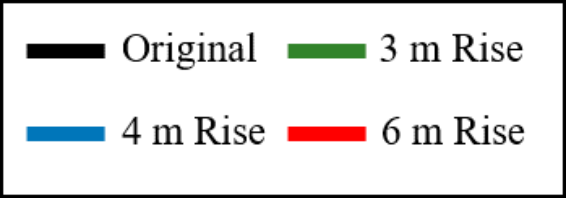

(a)

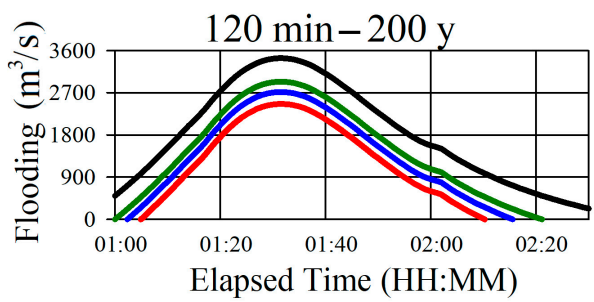

(c)

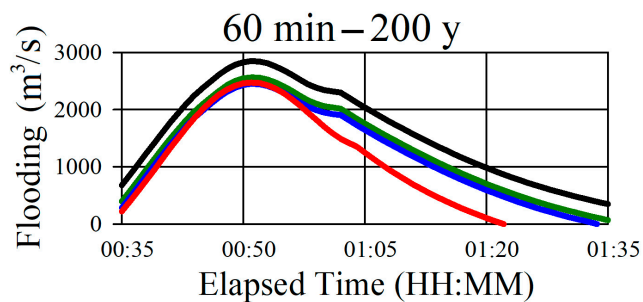

(b)

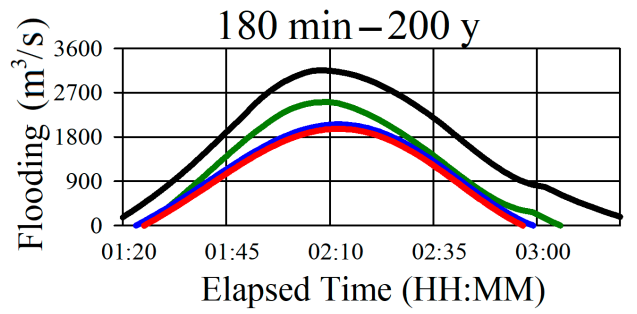

(d)

Figure 8. Flood reduction in the Suyeong River when the dam's height is raised (rainfall quantile). (a) Legend, (b) 60 min-200 year, (c) 120 min-200 year, (d) 180 min-200 year. 


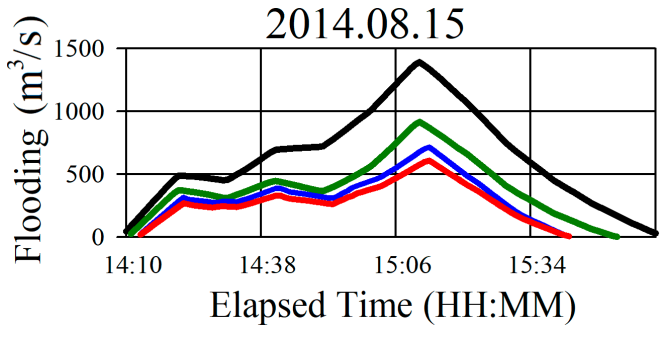

(a)

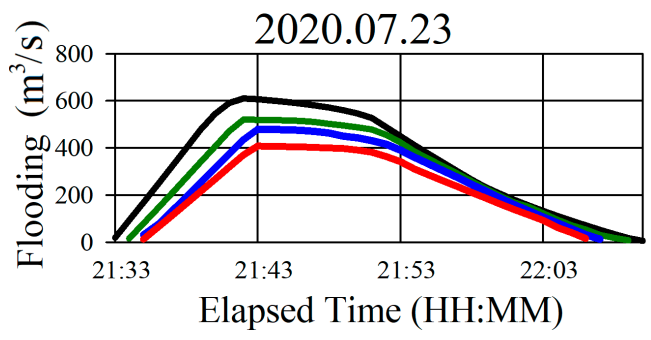

(b)

Figure 9. Flood reduction in the Suyeong River when the dam's height is raised (actual rainfall). (a) 2014.08.15; (b) 2020.07.23.

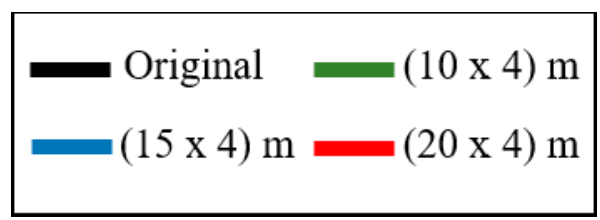

(a)

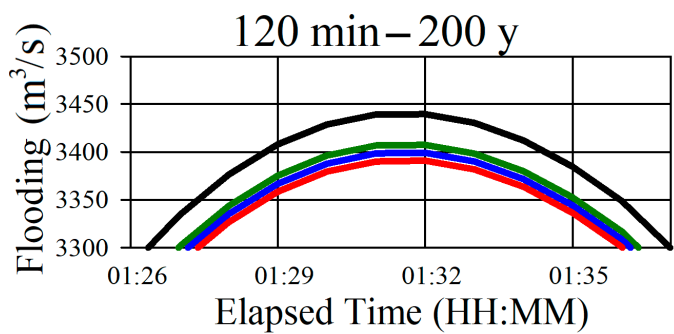

(c)

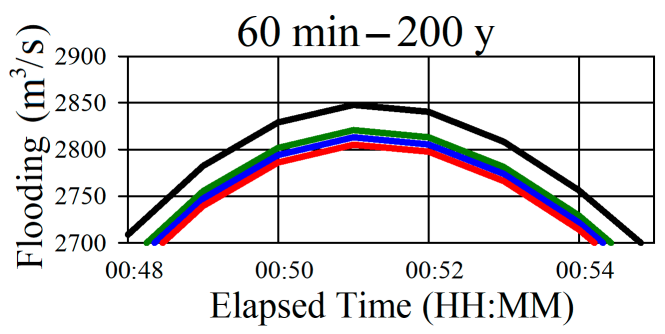

(b)

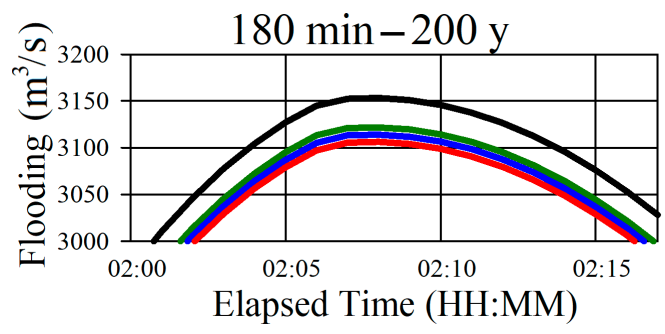

(d)

Figure 10. Flood reduction in the Suyeong River for various sizes of floodgate (rainfall quantile). (a) Legend, (b) 60 min-200 year, (c) 120 min-200 year, (d) 180 min-200 year.

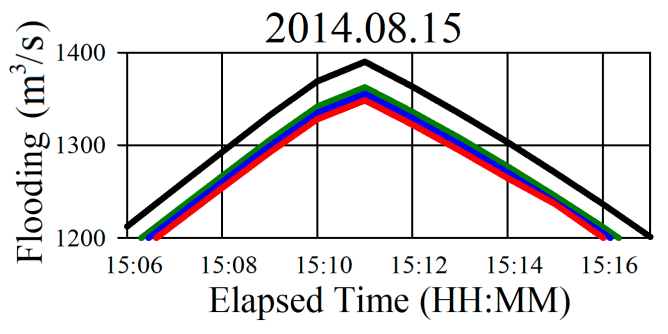

(a)

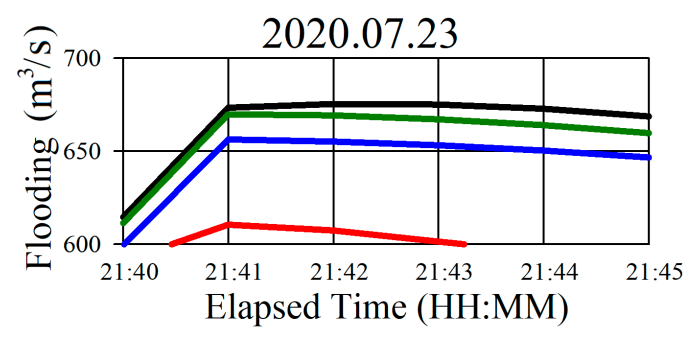

(b)

Figure 11. Flood reduction in the Suyeong River for various sizes of floodgate (actual rainfall). (a) 2014.08.15; (b) 2020.07.23. 


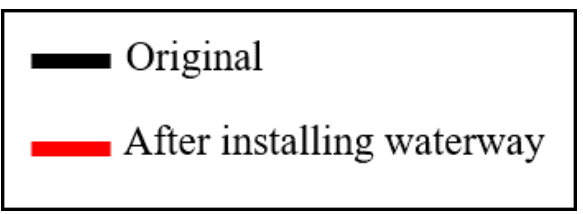

(a)

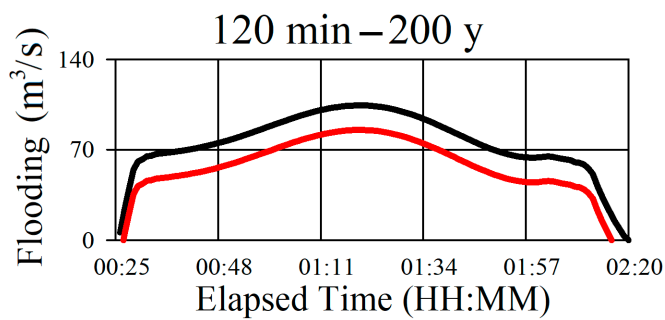

(c)

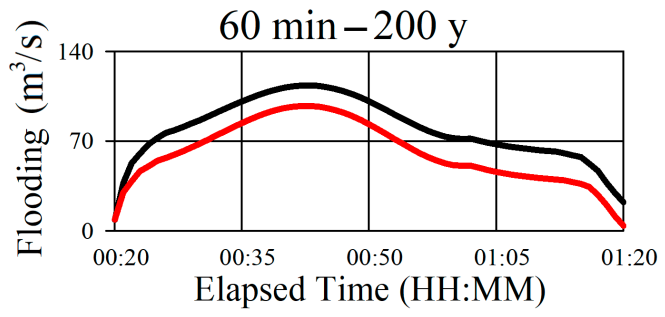

(b)

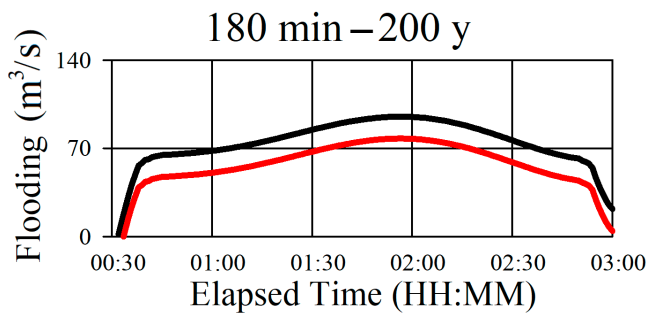

(d)

Figure 12. Flooding on the Oncheon River before and after installing the underground waterway (rainfall quantile). (a) Legend, (b) 60 min-200 year, (c) 120 min-200 year, (d) 180 min-200 year.

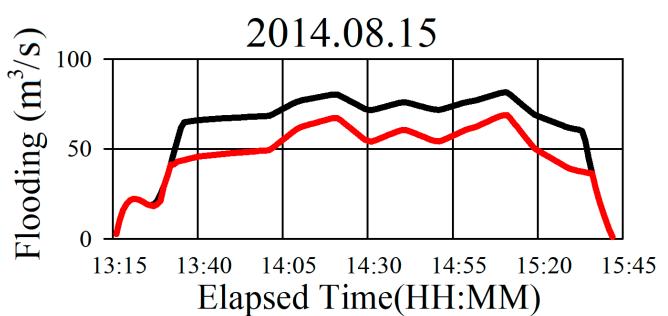

(a)

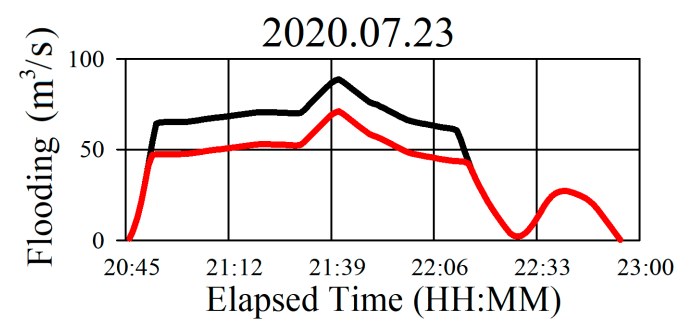

(b)

Figure 13. Flooding on the Oncheon River before and after installing underground waterway (actual rainfall). (a) 2014.08.15; (b) 2020.07.23.

The data on flood reduction rates in Table 1 show that the addition of an underground waterway would lead to less flooding. It is also worth noting, as shown in Figures 12 and 13, that the start time of flooding is later and the flooding ends sooner with a waterway than without.

Table 1. Flood reduction rates in the Suyeong and Oncheon rivers (rainfall quantile).

\begin{tabular}{|c|c|c|c|c|c|c|c|c|}
\hline \multirow{3}{*}{\multicolumn{2}{|c|}{$\begin{array}{c}\text { Duration- } \\
\text { Recurrence } \\
\text { Interval } \\
(\text { min) } \mid(y)\end{array}$}} & \multicolumn{7}{|c|}{ Reduction Rate of Flooding (\%) } \\
\hline & & \multirow{2}{*}{$\begin{array}{l}\text { Underground } \\
\text { Waterway }\end{array}$} & \multicolumn{3}{|c|}{ Raising Dam } & \multicolumn{3}{|c|}{ Floodgate } \\
\hline & & & $3 \mathrm{~m}$ & $4 \mathrm{~m}$ & $6 \mathrm{~m}$ & $\begin{array}{c}(10 \times 4) \\
\mathrm{m}\end{array}$ & $\begin{array}{c}(15 \times 4) \\
\mathrm{m}\end{array}$ & $\begin{array}{c}(20 \times 4) \\
\mathrm{m}\end{array}$ \\
\hline & & No. $9+900$ & & & & 45 & & \\
\hline \multirow{4}{*}{60} & 30 & 25.30 & 21.95 & 31.97 & 50.04 & 2.10 & 2.70 & 3.13 \\
\hline & 50 & 25.77 & 21.03 & 28.96 & 45.92 & 2.06 & 2.12 & 3.11 \\
\hline & 100 & 26.40 & 19.04 & 25.95 & 40.93 & 2.25 & 2.47 & 3.30 \\
\hline & 200 & 27.45 & 16.94 & 23.96 & 37.02 & 2.54 & 2.72 & 3.35 \\
\hline \multirow{4}{*}{120} & 30 & 24.02 & 32.03 & 45.05 & 50.00 & 2.62 & 2.88 & 3.41 \\
\hline & 50 & 24.09 & 29.17 & 41.25 & 50.01 & 2.84 & 2.97 & 3.53 \\
\hline & 100 & 24.54 & 26.01 & 37.05 & 49.96 & 2.73 & 2.87 & 3.46 \\
\hline & 200 & 25.00 & 23.98 & 34.01 & 49.95 & 2.75 & 2.88 & 3.50 \\
\hline
\end{tabular}


Table 1. Cont.

\begin{tabular}{|c|c|c|c|c|c|c|c|c|}
\hline \multirow{3}{*}{\multicolumn{2}{|c|}{$\begin{array}{c}\text { Duration- } \\
\text { Recurrence } \\
\text { Interval } \\
\text { (min) | (y) }\end{array}$}} & \multicolumn{7}{|c|}{ Reduction Rate of Flooding (\%) } \\
\hline & & \multirow{2}{*}{$\begin{array}{c}\text { Underground } \\
\text { Waterway }\end{array}$} & \multicolumn{3}{|c|}{ Raising Dam } & \multicolumn{3}{|c|}{ Floodgate } \\
\hline & & & $3 \mathrm{~m}$ & $4 \mathrm{~m}$ & $6 \mathrm{~m}$ & $\begin{array}{c}(10 \times 4) \\
\mathrm{m}\end{array}$ & $\begin{array}{c}(15 \times 4) \\
\mathrm{m}\end{array}$ & $\begin{array}{c}(20 \times 4) \\
\mathrm{m}\end{array}$ \\
\hline & & No. $9+900$ & & & & & & \\
\hline \multirow{4}{*}{180} & 30 & 22.52 & 39.03 & 48.10 & 50.13 & 2.77 & 2.90 & 3.63 \\
\hline & 50 & 23.28 & 36.03 & 41.96 & 50.10 & 2.80 & 2.94 & 3.70 \\
\hline & 100 & 23.36 & 33.02 & 45.96 & 49.98 & 3.21 & 3.50 & 3.97 \\
\hline & 200 & 23.99 & 30.03 & 41.98 & 49.96 & 3.33 & 3.64 & 4.01 \\
\hline
\end{tabular}

The effect on the Suyeong River when excess flow from the Oncheon is directed into the Hoedong reservoir via the underground waterway was modeled based on two scenarios (Table 2). The 60 min duration and 200 year return period scenario saw the inflow of water into the Suyeong River increase by $1.2 \%$. For the 180 min duration, 200 year return period scenario, the inflow increased by $0.7 \%$.

Table 2. Flood reduction rate in the Suyeong River and the Oncheon River (actual rainfall).

\begin{tabular}{|c|c|c|c|c|c|c|c|}
\hline \multirow{4}{*}{ Date } & \multicolumn{7}{|c|}{ Reduction Rate of Flooding (\%) } \\
\hline & \multirow{2}{*}{$\begin{array}{c}\text { Underground } \\
\text { Waterway }\end{array}$} & \multicolumn{3}{|c|}{ Dam Rise } & \multicolumn{3}{|c|}{ Floodgate } \\
\hline & & $3 \mathrm{~m}$ & $4 \mathrm{~m}$ & $6 \mathrm{~m}$ & $\begin{array}{c}(10 \times 4) \\
\mathrm{m}\end{array}$ & $\begin{array}{c}(15 \times 4) \\
\mathrm{m}\end{array}$ & $\begin{array}{c}(20 \times 4) \\
\mathrm{m}\end{array}$ \\
\hline & No. 9+900 & & & & o. 45 & & \\
\hline 2014.08.15 & 22.60 & 26.77 & 41.74 & 47.99 & 2.25 & 2.42 & 2.70 \\
\hline 2020.07.23 & 21.71 & 15.41 & 26.17 & 36.79 & 1.69 & 1.81 & 2.06 \\
\hline
\end{tabular}

The reason for this is that the Suyeong is a larger river than the Oncheon; its basin area is about four times larger, and water from the Oncheon, in this scenario, discharges into Hoedong Reservoir, rather than directly into the Suyeong, so that it flows through the dam after a short period of storage.

\section{Discussion}

Abnormal rainfall events are increasing worldwide every year, causing massive property damage and harm to human life. Sometimes the damage is serious, due to limitations in the capacity of urban drainage facilities when it comes to severe rainfall events. To prevent such damage, it is important to develop forecasting technology. It is also necessary to upgrade existing facilities and add new ones to meet the challenges posed by increasing rainfall intensity. This study analyzed the potential effects of new or upgraded facilities on extreme flooding in Busan, Korea, using the EPA-SWMM model to explore the effect of integrating local rivers and dams and adapting the existing infrastructure. The study showed a significant reduction in disaster risk as a result of these measures which, if applied, would make the urban areas of Busan safer. This research is relevant to climate change and its impacts.

Three scenarios were modeled: increasing the height of the dam, introducing floodgates of various sizes, and constructing an underground waterway to channel water from the Oncheon River to the Hoedong Dam on the Suyeong River.

A simulation was carried out to model the effects on the Suyeong River of raising the height of the Hoedong Dam. Based purely on the degree of flood reduction from this modification, it seems better to raise the height of the dam by $6 \mathrm{~m}$. However, it would be reasonable to raise the height of the dam by only $4 \mathrm{~m}$, because raising the height by $6 \mathrm{~m}$ would greatly increase pressure on the dam, causing a heightened flood risk to nearby villages. 
A simulation was carried out on the impact on the Suyeong River of adding a floodgate to the dam. The amount of flooding did not decrease significantly when only the floodgate was installed. However, when opening and closing of the floodgate was adjusted based on the water level at a downstream flood risk point, the degree of flooding was reduced to a certain extent. This suggests that if floodgates were installed and structural analysis was carried out to calculate the appropriate height of the dam, it would greatly reduce the amount of flooding in the metropolis near the Suyeong River.

A simulation was carried out to model the impact of an artificial underground waterway connecting the Oncheon and Suyeong rivers, to reduce flooding on the Oncheon and also protect, restore and promote the sustainable use of ecosystems around Busan. When discharge was sent from the Oncheon to the Suyeong, the amount of flooding increased by about $1 \%$ at the flooding hazard point on the Suyeong. However, since the Suyeong River has a large basin with about four times the drainage area compared to the Oncheon River, it is believed that sending the discharge to the Suyeong would not affect this river.

\section{Conclusions}

This study proposed methods to minimize damage during abnormal rainfall caused by flooding on the Suyeong and Oncheon, two important urban rivers in Busan, Korea. The Hoedong Dam, located in the middle reaches of Suyeong River, was used. It was found that by connecting the Oncheon River to the Hoedong Dam via an underground waterway, it is possible to both reduce the amount of flooding and reduce the time period over which flooding takes place, allowing authorities more time to respond.

In addition, the storage volume of the reservoir can be increased by raising the height of the existing dam, and the level of discharge can be adjusted by installing floodgates, both of which help to reduce flood rates and periods. In order to show this, a comparative analysis was conducted on the level and the start time of flooding at selected points on the Suyeong and Oncheon rivers where flooding is known to occur in the event of heavy rain.

The results obtained showed a significant amount of flood reduction from these methods. This suggests that they can be expected to reduce flood damage, even if abnormal rainfall has not been forecasted. Furthermore, it is believed that citizens' lives and property could be greatly protected by these measures in dense urban areas such as Busan, Korea, and that they can react to rapid changes in the climate.

However, this study modeled the effect of flood reduction by means of EPA-SWMM, which has some limitations. It had no option to input the range of submerged areas following augmentation of the dam's capacity, and the surrounding environment could not be analyzed due to the limits of the software. Therefore, further research is required on the expected range of submerged areas and the impacts on the surrounding environment resulting from any enhancement of the dam.

Author Contributions: Y.-M.C. and Y.-W.C. conceptualized the research. Y.-M.C., S.-B.S., Y.-W.C. carried out the investigation. Y.-M.C. wrote the manuscript. Y.-W.C. conceived the methodology of the proposed method. All authors have read and agreed to the published version of the manuscript.

Funding: This research was funded by the Brain Korea 21 FOUR Project in the Education \& Research Center for Infrastructure of Smart Ocean City (i-SOC Center).

Institutional Review Board Statement: Not applicable.

Informed Consent Statement: Not applicable.

Data Availability Statement: Not applicable.

Acknowledgments: This research was supported by the Brain Korea 21 FOUR Project in the Education \& Research Center for Infrastructure of Smart Ocean City (i-SOC Center).

Conflicts of Interest: The authors declare no conflict of interest. 


\section{References}

1. Jorge, L.; Chen, K.F.; Wood, R.R.; Ludwig, R. A scalable flood-resilience-index for measuring climate change adaptation: Munich city. Water Res. 2020, 173, 115502. [CrossRef]

2. Tabari, H. Extreme value analysis dilemma for climate change impact assessment on global flood and extreme precipitation. J. Hydrol. 2021, 593, 125932. [CrossRef]

3. Hoang, L.; Fenner, R.A.; Skenderian, M. A conceptual approach for evaluating the multiple benefits of urban flood management practices. J. Flood Risk Manag. 2016, 11, S943-S959. [CrossRef]

4. Vercruysse, K.; Dawson, D.A.; Wright, N. Interoperability: A conceptual framework to bridge the gap between multifunctional and multisystem urban flood management. J. Flood Risk Manag. 2019, 12, e12535. [CrossRef]

5. Wu, Z.; Shen, Y.; Wang, H.; Wu, M. Urban flood disaster risk evaluation based on ontology and Bayesian Network. J. Hydrol. 2020, 583, 124596. [CrossRef]

6. Mei, C.; Liu, J.H.; Wang, H.; Wang, L.Z.; Yang, Z.Y.; Shao, W.W.; Ding, X.Y.; Weng, B.S.; Yu, Y.D.; Yan, D.Y. Urban flood inundation and damage assessment based on numerical simulations of design rainstorms with different characteristics. Sci. China Technol. Sci. 2020, 63, 2292-2304. [CrossRef]

7. Cristiano, E.; Farris, S.; Deidda, R.; Viola, F. Comparison of blue-green solutions for urban flood mitigation: A multi-city large-scale analysis. PLoS ONE 2021, 16, e0246429. [CrossRef] [PubMed]

8. Blazkova, S.; Beven, K. Flood frequency estimation by continuous simulation of subcatchment rainfalls and discharges with the aim of improving dam safety assessment in a large basin in the Czech Republic. J. Hydrol. 2004, 292, 153-172. [CrossRef]

9. Badenko, V.; Badenko, N.; Nikonorov, A.; Molodtsov, D.; Terleev, V.; Lednova, J.; Maslikov, V. Ecological Aspect of Dam Design for Flood Regulation and Sustainable Urban Development. MATEC Web Conf. 2016, 73, 03003. [CrossRef]

10. Mei, X.; Dai, Z.; Darby, S.E.; Gao, S.; Wang, J.; Jiang, W. Modulation of Extreme Flood Levels by Impoundment Significantly Offset by Floodplain Loss Downstream of the Three Gorges Dam. Geophys. Res. Lett. 2018, 45, 3147-3155. [CrossRef]

11. Sharif, A.; Hansen, D. Application of SWMM to the flooding problem in Truro, Nova Scotia. Can. Water Resour. J. 2001, 26, 439-459. [CrossRef]

12. Jang, S.J. A study on the proper size of rainwater stored tank in submerged districts using SWMM program. J. Korean Hous. Assoc. 2009, 20, 69-76.

13. Lee, J.H.; Song, Y.H.; Jo, D.J. Determination of optimal locations of urban subsurface storage considering SWMM parameter sensitivity. J. Korean Soc. Hazard Mitig. 2013, 13, 295-302. [CrossRef]

14. Shin, D.S.; Park, J.B.; Kang, D.K.; Jo, D.J. An analysis of runoff mitigation effect using SWMM-LID model for frequently inundated basin. J. Korean Soc. Hazard Mitig. 2013, 13, 303-310. [CrossRef]

15. Jiang, L.; Chen, Y.; Wang, H. Urban flood simulation based on the SWMM model. In Proceedings of the RSHS14 and ICGRHWE14, Guangzhou, China, 24-27 August 2015; Volume 368, pp. 186-191. [CrossRef]

16. Kim, J.S.; Lee, W.H. Flood inundation analysis in urban area using XP-SWMM. J. Korean Geoenviron. Soc. 2015, 16, 29-36. [CrossRef]

17. Rai, P.K.; Chahar, B.R.; Dhanya, C.T. GIS-based SWMM model for simulating the catchment response to flood events. Hydrol. Res. 2017, 48, 384-394. [CrossRef]

18. Babaei, S.; Ghazavi, R.; Erfanian, M. Urban flood simulation and prioritization of critical urban sub-catchments using SWMM model and PROMETHEE II approach. Phys. Chem. Earth 2018, 105, 3-11. [CrossRef]

19. Hasan, H.H.; Razali, S.F.M.; Zaki, A.Z.L.A.; Hamzah, F.M. Integrated Hydrological-Hydraulic Model for Flood Simulation in Tropical Urban Catchment. Sustainability 2019, 11, 6700. [CrossRef]

20. Choo, Y.M.; Jo, D.J.; Yun, G.S.; Lee, E.H. A Study on the improvement of flood forecasting techniques in urban areas by considering rainfall intensity and duration. Water 2019, 11, 1883. [CrossRef]

21. Ministry of Land, Transport and Maritime Affairs. A Study on the Improvement and Complementation of Probabilistic Rainfall; The Korean Government: Gwacheon, Korea, 2011; pp. 145-175. 